\title{
HidROFOBIA MEDIEVAL: MIEDOS Y PELIGROS VINCULADOS AL AGUA EN LA LITERATURA CASTELLANA DEL XV
}

\author{
Jorge LeBrero Cocho*
}

Universidad de Valladolid

\begin{abstract}
Resumen
El estudio del miedo ofrece una perspectiva muy sugerente para el abordaje de la Historia de las mentalidades. Pese a que, como objeto de estudio, el miedo ha incrementado su presencia en trabajos recientes, los investigadores se han centrado en ámbitos sustancialmente diferentes al aquí tratado. El agua, fuente de energía, vía de comunicación y recurso imprescindible para toda vida, ha sido vista también con suspicacia y su contacto con ella afrontado con especial prevención, de manera absoluta cuando hablamos del mar y de los lógicos peligros que entraña. Hemos recurrido a algunas de las obras literarias castellanas más conocidas del ocaso de la Edad Media para tratar de entender qué recelos e inseguridades generaba el agua a sus contemporáneos.
\end{abstract}

\section{Palabras clave}

Agua, miedo, literatura, S. XV, Castilla.

\begin{abstract}
Studies about fear can offer an interesting perspective for addressing the History of mentalities. Although fear as a field of study has enlarged its presence in recent works, researchers have focused on aspects different from those we have dealt with. Water, as an energy source, a communication route and a resource essential to life, has also been seen with distrust, and the contact with it has been faced with caution, especially when referring to the sea and its hidden dangers. We have examined some of the best-known literary works from the Late Middle Ages in Castile in an attempt to understand the suspicions and insecurities connected with water that the people from the Middle Ages felt.
\end{abstract}

\section{Keywords}

Water, fear, literature, 15th Century, Castile.

\section{Résumé}

Étudier la peur offre une perspective très suggestive pour aborder l'Histoire des mentalités. Bien que la peur en tant qu'objet d'étude ait vu sa présence s'imposer de plus en plus dans des travaux récents, les chercheurs se sont concentrés sur des domaines sensiblement différents de celui que nous traitons ici. Source d'énergie, voie de communication et ressource indispensable pour toute forme de vie, l'eau a été considérée aussi avec méfiance et son contact traité avec une prévention spéciale, de

\footnotetext{
* Becario de investigación FPU del Ministerio de Educación, Cultura y Deporte en el Departamento de Historia Antigua y Medieval de la Universidad de Valladolid. E-mail: aegis.jlc@gmail.com
} 
manière absolue lorsque l'on parle de la mer et des dangers logiques qu'elle entraîne. Nous avons eu recours aux œuvres littéraires castillanes des plus connues de l'automne du Moyen Age pour tenter de comprendre les craintes et les incertitudes provoquées par l'eau à cette époque.

\section{Mots-clés}

Eau, peur, littérature, XVe siècle, Castille.

\section{Introducción}

Queremos proponer en estas líneas una brevísima aproximación a la comprensión del elemento líquido desde una óptica tal vez menos convencional: ni su disfrute, ni su gestión, ni su empleo son nuestro objeto de estudio. Nuestra voluntad es reflexionar sobre parte de la construcción cultural que los hombres del Medievo establecen en base al agua. En las sociedades preindustriales, el contacto con cualquier elemento de la naturaleza (animal, vegetal, geológico, astronómico...) es más directo e intenso que el que podamos mantener en nuestros días. Según Gurievich ${ }^{1}$, es a finales de la Edad Media cuando el hombre comienza a levantar barreras con una naturaleza que antes consideraba unida a sí mismo, adquiriendo cierta perspectiva de una individualidad y especificidad del ser humano respecto al entorno en el que desarrolla su existencia cotidiana. La naturaleza genera en las personas sentimientos encontrados de admiración y sometimiento, de atracción y rechazo, siempre enmarcados en el contexto de la absoluta dependencia de ella. Nos centraremos solamente en una de las caras del poliédrico asunto, en su reverso nocivo: puesto que el contacto con el agua esconde riesgos se le debe una actitud respetuosa, que nos acompaña desde lo más antiguo. Cuando no se pueda hablar directamente de miedo, al menos existe una buena dosis de precaución ante los daños evidentes que generan la tormenta, la inundación, el emponzoñamiento de las aguas para el consumo, el mar enfurecido, la bestia acuática ${ }^{2} .$. El agua tiene una presencia destructiva desde la base misma de la cosmovisión cristiana de la existencia, o, lo que es lo mismo, ya aparece claramente en la tradición veterotestamentaria: recordemos que el Diluvio Universal, de entre todas las posibilidades al alcance de Dios, es el método elegido para el castigo supremo a la humanidad corrompida, castigo universalizante; o cómo aplasta el mar al ejército egipcio, salvando al pueblo de Moisés; o que algún Leviatán puede tragarse profetas indisciplinados, aunque sea para escupirlos al tercer día ${ }^{3}$. Sin embargo, también ejerce su papel purificador y redentor, plasmado en los Evangelios: la entrada a la gran familia cristiana, y por tanto a la posibilidad de la salvación eterna, se hace primeramente a través del bautismo con agua.

Olvidémonos unos instantes del pánico irracional al contacto con el agua, síntoma por cierto de la rabia; atendamos aquí a la "hidrofobia" como figura literaria que nos

Arón Guriévich, Las categorías de la cultura medieval, Taurus, Madrid, 1990.

La mayoría de las referencias girarán, sin embargo, en torno a los desafíos que presenta la navegación.

Para estos pasajes bíblicos, véase, respectivamente, Gn 6-8, Ex 14 y Jon 1-2. 
hemos permitido utilizar para el título. El miedo -que viene precedido del peligrono es más que la búsqueda de una seguridad, estado que es difícil de encontrar aún ahora. El peligro, a nuestros ojos, puede tener fundamento o ser imaginario, objetivo o subjetivo, pero lo fundamental es cómo, bajo qué prisma, con qué intensidad lo percibe un hombre o mujer cualquiera del XV. El riesgo es entonces siempre real y vivo. Dividir y clasificar estos peligros entre científicos y sobrenaturales según una óptica contemporánea nos entorpecería a la hora de asaltar la mentalidad medieval de una forma coherente e integral. En la Edad Media una tormenta o una sirena son creaciones naturales de Dios, diferenciadas entre sí más por la frecuencia con la que se pueden observar que por su existencia empírica. Hay que añadir que ninguna creación divina es neutra, sino que conlleva una importante carga simbólica y representativa ${ }^{4}$. Para su comprensión y racionalización, la breve experiencia personal significa poco frente a las sentencias de las autoridades clásicas al respecto, al conocimiento acumulado por el conjunto de la sociedad tradicional y la cultura anclada en la oralidad popular.

\section{Fuentes para una aproximación}

El agua como objeto de estudio histórico lleva siendo trabajado desde hace más de 15 años por un grupo de reconocidos historiadores de la Universidad de Valladolid. Desde el primer momento, este conjunto de profesionales se planteó cómo confrontar al desafío que presentaban las fuentes ${ }^{5}$, exponiendo en seminarios y publicaciones la existencia de insospechados "informantes" muy útiles para abordar el asunto del agua en el periodo. En nuestro caso, parece evidente que entre los vestigios del pasado, para abordar una parcela histórica que podría denominarse como "sentimental" o "emotiva", hay que centrarse principalmente en las fuentes escritas. Por la propia esencia del asunto, el eje básico es la literatura. Y de entre el nutrido elenco de las letras castellanas, las fuentes escogidas para este breve estudio están vinculadas entre sí por la omnipresencia del viaje, aunque no todos los documentos empleados se puedan considerar estrictamente "libros de viajes" o "literatura de viajes". Entre los restos literarios del pasado medieval abunda la presencia de aguas lindas, claras, buenas, ricas, salubres o milagrosas: no faltan en los feraces jardines y huertas o en los entornos paradisiacos; las riberas fluviales invitan al descanso en sus prados, mientras que algunas ciudades están maravillosamente canalizadas o constan de

\footnotetext{
4 Jacques Le Goff, La civilización del Occidente Medieval, Juventud, Barcelona, 1969.

5 Véase $\mathrm{M}^{\mathrm{a}}$ Isabel Del Val Valdivieso (coord.), El agua en las ciudades castellanas durante la Edad Media. Fuentes para su estudio, Universidad de Valladolid, Valladolid, 1998.

6 Sobre el concepto, delimitaciones y debates al respecto de estos términos, vid. Luis Alburquerque García, "Algunas cuestiones disputadas sobre el género 'relato de viajes", Boletín Hispánico Helvético, 20 (2012), pp. 99-114. También de reciente factura es el trabajo de Victoria BÉGUELIN-ArgimÓN, La geografía en los relatos de viajes castellanos del ocaso de la Edad Media. Análisis del discurso y léxico, Hispania-Helvética, Lausana, 2011. En él encontramos un corpus bastante similar al empleado aquí, y un análisis que incluye elementos climáticos, faunísticos, mitológicos, marítimos y fluviales de los que hablaremos en estas líneas.
} 
hermosas cisternas y fuentes que merecen la atención del escritor. Pero como es habitual en la Edad Media, la dicotomía se impone: el agua tiene un dorso lúgubre muy explotado en la cultura escrita como objeto o escenario del desastre, de la destrucción y del pecado.

Utilizaremos para esta reflexión una breve relación de obras ampliamente conocidas de nuestro pasado medieval, pese a que rozan cronológicamente la modernidad:
a) Embajada a Tamorlán?
b) El Victorial ${ }^{8}$.
c) Andanzas y viajes de un hidalgo español$l^{9}$.
d) Diario de Colón ${ }^{10}$.

Estos libros suponen algunos de los mejores testimonios en prosa con que contamos en Castilla para el siglo XV y en ellos tiene un papel decisivo la navegación -marítima y fluvial- como transporte eficaz e irremplazable, por lo que se encuentran abundantes reseñas náuticas que los convierten en objeto preferente de nuestro estudio ${ }^{11}$. Pero

\footnotetext{
7 Relato del viaje de la comitiva de Ruy González de Clavijo como emisario de Enrique III. Data de 1406, escrita inmediatamente tras el regreso de la comitiva por el mismo Clavijo o por otro miembro de la delegación (se ha apuntado también a fray Alfonso Páez de Santa María como posible autor o coautor). Utilizaremos Ruy González de Claviso, Embajada a Tamorlán, ed. Francisco López Estrada, Castalia, Madrid, 1999.

8 Biografía "caballeresca" de Pero Niño, elaborada por Gutierre Díaz a petición y sueldo del protagonista; se cree que hacia 1431 se encarga su redacción definitiva, cuando Pero Niño recibe el condado de Buelna pero se desconoce el momento exacto y las fases de su redacción, aunque probablemente buena parte de la obra se basaría en un diario de a bordo. Nos interesan especialmente sus campañas militares en el Mediterráneo y Atlántico al servicio de Castilla. Se empleará Gutierre Díaz De Games, El Victorial, ed. Rafael Beltrán Llavador, Ediciones Universidad de Salamanca, Salamanca, 1997.

9 Se considera que la composición tiene lugar en 1454 por parte de su protagonista, Pero Tafur, al menos 15 años después de que finalizara la aventura. Aparentemente, el autor no tuvo intención de escribirlo hasta que nuevas motivaciones personales o políticas no del todo claras le impulsan a ello. Pero TAFur, Andanças e viajes, ed. Miguel Ángel Pérez Priego, Fundación José Manuel Lara, Sevilla, 2009.

10 Concretamente lo que ha llegado a nosotros es la transcripción del diario que realizara Bartolomé de las Casas en la década de 1530, al parecer sobre otro texto que no fue el escrito por el Almirante sino uno ligeramente alterado para evitar el conflicto con Portugal por el quebrantamiento del Tratado de Alcaçovas; se considera, no obstante, que conserva en lo fundamental el contenido que expresó Colón en su diario de a bordo. Basamos nuestras citas vinculadas al Diario en Cristóbal Colón, Diario, eds. Jesús Varela Marcos y Juan Manuel Fradejas Rueda, Instituto Interuniversitario de Estudios de Iberoamérica y Portugal, Valladolid, 2006.

11 Para ahondar en la visión que ofrece la literatura de la época sobre los mares, es indispensable acudir a la obra de Alberto NaVArRo GonzÁlez, El mar en la literatura medieval castellana, Universidad de la Laguna, La Laguna, 1962. Acerca de un panorama más global sobre la navegación en el Medievo, Archibald R. Lewis y Timothy J. RunYAn, European Naval and Maritime History, 300-1500, Indiana University Press,
} 
también contienen otras referencias sobre cuestiones hídricas de enorme interés, como veremos más adelante. La clara esencia personal de los textos refleja además nítidas relaciones entre los personajes y el agua.

Las motivaciones que empujan a emprender el camino a cada uno de sus protagonistas varían, abarcando las diplomáticas, militares, el recreo aventurero y la expedición descubridora. De entre ellos, solo Cristóbal Colón es navegante de profesión -con permiso de Pero Niño, que se convierte en corsario de facto- y tiene una relación con el agua que va mucho más allá de lo circunstancial. Nos hemos apartado también de los ámbitos de creación religiosa, que han perdido su hegemonía para entonces, atendiendo sobre todo a autores seglares que contribuyen a abordar los periplos de la movilidad en la época con una impronta profana. Lógicamente no sólo las causas de los viajes difieren; la puesta por escrito de la experiencia de éstos busca también unos fines particulares muy concretos, lo que afecta de forma notable al tratamiento de los textos: Clavijo -o el autor de la Embajada, en caso de no haber sido él- da relación de una misión política; Gutierre Díaz considera su cometido principal ensalzar la figura y amplias cualidades del contratante de la obra y de su linaje, "loar los fechos de un buen caballero" 12 , en sus propias palabras; Tafur hace lo propio con la particularidad de ser un relato autobiográfico y más apegado a los nuevos gustos del momento; mientras que el último elabora un diario que procura sobre todo fijar una ruta. En cualquier caso, toda obra se confecciona con la finalidad de ser leída y el autor o promotor tiene que ver satisfechas sus expectativas y demandas personales en primer lugar; en otras palabras, el texto siempre jugará a favor del protagonista intencionadamente.

El lector-oyente reclama acción, aventura, épica, y el autor se presta al teatro. El viaje no puede ser solamente una acumulación descriptiva de datos de las distintas etapas o destinos, precisa igualmente de la vivencia íntima del camino. Yendo más allá, los narradores incorporan con facilidad episodios, historias, leyendas, sucesos ajenos, anécdotas, mirabilia, etc., que les cuentan o que averiguan y que remozan las obras; no podemos olvidar que estamos inmersos en una etapa histórica que vive muy lentamente el proceso de sustitución del conocimiento mediante el oído por el conocimiento experimental mediante la vista ${ }^{13}$. Los autores consideraron suficientemente relevantes tales apostillas como para reservarles un hueco distinguido en sus obras. Sin embargo, es necesario desterrar el tópico de la absoluta credulidad del hombre medieval; no faltan las referencias a las fuentes fiables de estas informaciones, a quienes por autoridad, antigüedad, reputación o sabiduría se les presupone la capacidad para certificar u otorgar veracidad a las experiencias más asombrosas. Por eso cuando la fuente es de dudosa credibilidad, el autor se aparta oportunamente y salvaguarda su reputación.

Bloomington, 1985, pp. 144-163; Susan Rose, The Medieval Sea, Hambledon Continuum, Londres-Nueva York, 2007; Miguel Ángel Ladero Quesada, "L'Espagne et l'océan à la fin du Moyen Age", L'Europe et l'Océan au Moyen Age. Contribution à l'Histoire de la Navigation, Société des Historiens Médiévistes de l'Enseignement Supérieur-Cid Editions, Nantes, 1988, p. 115-130.

12 Gutierre Díaz de Games, El Victorial..., pp. 209-210.

13 Paul Zumpthor, La medida del mundo, Ediciones Cátedra, Madrid, 1994, p. 295. 
Por último, algunas otras obras literarias de los últimos siglos de la Edad Media, con variada temática y propósito, sirven para complementar las pinceladas sobre el asunto. Dejamos al margen, por el momento, recursos tan ricos como la iconografía, la pintura y otras expresiones artísticas plásticas, sin albergar ninguna duda de que nos aportarían información de relevancia y sin los cuales el panorama aquí relatado queda de antemano en desequilibrio.

\section{Mares y tormentas}

El océano es el principal espacio del agua, su origen y su tumba. Como no puede ser de otra forma, es en este inmenso desierto líquido donde más fácilmente puede perder la vida el hombre; y decimos el hombre, porque como muchos otros espacios, actividades y contextos, el mar es un mundo eminentemente masculino, aunque nunca totalmente vedado a las mujeres, tampoco en la literatura. Esa, la de la vida, sí que es una pérdida importante, más que cualquier otro bien terreno, al menos para la mayoría de los mortales (aunque Pero Niño manifieste preferir fallecer antes que quedar mutilado e inservible para sus funciones nobles, pero es una obvia excepcionalidad amoldada al marco del heró́smo caballeresco y al ideal de buena muerte) ${ }^{14}$. Por supuesto, lo más valioso que se trata de conservar en óptimas condiciones es el alma; como veremos, se cuidan bastante de no ser olvidados por Dios cuando están a merced de la muerte. El mejor cristiano es con frecuencia el que se ve a las puertas de su expiración. En estas obras se suceden las descripciones de naufragios con relativa frecuencia, base material para que el miedo al mar esté plenamente justificado. Errores humanos hacen chocar los navíos con rocas o bajos fondos, encarnizadas luchas contra infieles o entre los mismos cristianos siembran la costa de pecios, el desigual trabajo de los armadores y calafateadores hace que se cuelen las aguas en el casco... Cierto, pero sobre todo son las tormentas las que dan al traste con la mayoría de las embarcaciones que se hunden ${ }^{15}$.

"Desde la antigüedad no hay epopeya sin tormenta"16 dice Delumeau. Esto se encuentra presente en obras de poesía narrativa y ficción a lo largo de toda la Edad Media; así es el caso del célebre Libro de Apolonio, donde el viaje marítimo, el mar yrado y el

\footnotetext{
14 Un breve estudio sobre la concepción de la muerte acaecida en defensa de la patria, la tierra y la fe en Ariel Guiance, Los discursos sobre la muerte en la Castilla Medieval (siglos VII-XV), Junta de Castilla y León, Valladolid, 1998, pp. 325-355.

15 Así se aprecia también en Las Siete Partidas del rey don Alfonso el Sabio, cotejadas con varios códices antiguos por la Real Academia de la Historia, Atlas, Madrid, 1972, t. 3, Partida V, Título IX, pp. 236-245. Los naufragios fueron tan habituales y conllevaban pérdidas tan importantes que tienen una extensa dedicación legislativa en esta obra. La preocupación por el contencioso sobre los bienes y responsabilidades a bordo de un navío que se hunde queda patente. Para asuntos vinculados a la guerra marítima, atiéndase al t. 2, Partida II, Título XXIV, pp. 258-267; para el XV, los estudios de María Teresa Ferrer Mallol, Corsarios castellanos y vascos en el mediterráneo medieval, CSIC, Institución Milá y Fontanals, Barcelona, 2000.

16 Jean Delumeau, El miedo en Occidente, Taurus, Madrid, 2012, p. 50 y ss.
} 
naufragio rememoran tópicos odiseicos y vertebran la historia ${ }^{17}$. No es que dudemos de la vivencia real de nuestros protagonistas de estos episodios en los que se narran poderosas tempestades; de hecho nos encontramos algunas de las más bellas descripciones de las tormentas marítimas y de otras experiencias a bordo; su inclusión tan detallada y viva en los relatos refleja el tremendo impacto que tuvieron que causar y disipa casi cualquier duda acerca de la veracidad de dichos pasajes. Sentirse tan cerca de la muerte deja una profunda huella y el privilegio de sobrevivir merece ser contado como una proeza. La tormenta en travesía supone la alianza entre las aguas del cielo y del mar, que se coordinan para devorar al frágil producto humano que es el navío y a la atrevida e insensata tripulación que lo pilota. Por mucho que se eviten los tiempos menos propicios para la navegación no hay ninguna garantía de no ser alcanzado por un temporal en cualquier estación del año.

Si nos atenemos a las fuentes mencionadas, ¿cómo se viven estas tormentas que hacen peligrar a los navegantes? Sin duda, con pavor, pero en esto hay muchos matices. Nos explicamos.

Entre los marineros asustadizos surge el héroe, ocupando la plaza del coraje. Da pie a discursos bravos, enaltecedores de los corazones flacos. Es el caso de Pero Niño, que en una cruenta tempestad en el Mediterráneo en la que se introduce contra el consejo de los pilotos, brilla como un titán. Mientras sus hombres corren a esconderse al fondo de la nave, él se asombra de su temor, gritándoles que "tan grandes olas fazía un río cuando faze buen viento"18. Delimitar si pasajes como estos se corresponden con sucesos reales o con meras licencias propagandísticas, estimuladas directamente por el beneficiario o de la cosecha intelectual del autor, es harto complicado. Niño es ensalzado permanentemente en la obra, por lo que presumimos que no es más que otro capítulo dentro de la tendencia general de adular todos sus gestos y discursos, pero bien es cierto que siendo el capitán y perteneciendo a un estamento privilegiado no se espera menos de él. Es importante reparar en que existe una profunda asimilación entre el miedo y la cobardía, y que ésta última impacta fuertemente contra los valores de la caballería. En cualquier caso, problema de oficio: ¿cómo superar al héroe protagónico para llegar a los sentimientos y comportamientos del conjunto de la tripulación ${ }^{19}$ ? La valentía del superhombre respecto al pánico de los demás está claramente dramatizada, pero probablemente el desasosiego generalizado de los tripulantes esté acorde con la realidad y no necesite de una humillación planificada ni de exageraciones. En cualquier caso, es irrebatible que se recurre a los sufrimientos de la marinería en el texto solo para destacar el contraste con el arrojo que demuestra

\footnotetext{
17 María Jesús Lacarra y Juan Manuel Cacho Blecua, Historia de la literatura española. 1. Entre oralidad y escritura. La Edad Media, Crítica, Barcelona, 2012, p. 366.

18 Gutierre Díaz de Games, El Victorial..., p. 394.

19 Superando las breves y despreocupadas notas sobre la marinería que aporta la literatura, tenemos documentos de variado origen para acercarnos a ellos. Vid. los diferentes artículos presentados en 2011 en los VIII Encuentros Internacionales del Medievo de la ciudad de Nájera, recogidos en Jesús A. Solórzano Telechea, Michel Bochaca y Amélia Aguiar Andrade (eds.), Gentes de mar en la ciudad atlántica medieval, Instituto de Estudios Riojanos, Logroño, 2012.
} 
Niño, fenómeno extrapolable al resto de conductas. El patrocinador de la obra no quiere falsas modestias, con las que los autores solían referirse a sí mismos, sino que paga orgulloso para acrecentar su honra y fama.

Sin embargo, tampoco faltan ocasiones en las que Gutierre Díaz prescinde de extraer a Niño del comportamiento del conjunto de los tripulantes: partiendo de Bretaña, un gran oleaje embiste las galeras. Todos se van a la parte baja del navío, cerrando las escotillas: temerosos de morir allí hacen los hombres votos y prometimientos, cada uno donde mejor cree conveniente; es de suponer que Niño, cristianísimo, haría lo propio. La devoción y la fe son al fin y al cabo valores transversales, obligatorios a todos, independientemente de su condición social. Tal vez la figura del héroe aplaste literariamente a los marineros, pero ante Dios siempre hay que humillarse. Decíamos que sobrevivir a la tormenta es una experiencia digna de narrarse. Tras la gran borrasca que acabamos de exponer, toda la flota se disemina por el Atlántico, y las tripulaciones de cada nave dan por perdidos o muertos al resto de la compañía. Cuando al cabo de un tiempo se reencuentran a salvo, se reúnen en tierra para hacer un festín y cada uno relata las aventuras que soportó la noche de la tormenta, sin ocultar el gran susto padecido. Como no puede ser de otra forma, cierra el capítulo la intervención de Niño, reclamando fe y fortaleza contra las adversidades ${ }^{20}$. No nos olvidemos del papel que venían jugando en la gesta los discursos heroicos ante las asambleas, reforzando ante la comunidad el liderazgo del protagonista, que dicta sentencia.

Vamos a otro caso. Pero Tafur también navega bastante, en su caso exclusivamente por el Mediterráneo y el Mar Negro. Aunque su origen es noble, viaja sin mandato alguno reconocido: por placer, por curiosidad, por devoción, pero también por labrarse un nombre. No tiene que justificar un heroico comportamiento, al menos no con la misma intensidad o bajo los mismos parámetros que otros caballeros, pues el viaje en sí mismo es una proeza suficiente ${ }^{21}$. Reflejando buena parte de su personalidad en sus Andanzas, son varias las ocasiones en las cuales demuestra verdadera angustia ante la navegación. Tan vivos debían de estar en su recuerdo -o en sus anotaciones- los episodios tormentosos en la mar que quince años después del viaje aún nos sobrecoge su relato. No esconde el recelo que le produjeron tales experiencias, aunque lo hace de una manera un tanto mordaz que las rebaja casi hasta el chiste. Veamos algunos ejemplos:

Al llegar a Génova después de un largo viaje en barco marcha a la posada "cansado e enojado e mareado e quito de toda ufana"22. Solo se ha detenido antes a rezar en Santa Coronata, cumpliendo los votos que hizo durante una tormenta. En otro punto del viaje son perseguidos por un navío turco. Se libran de él en la oscuridad remando sin ruido, pero al poco comienza el oleaje, que les sacude enérgicamente. Exclama entonces Tafur: “¡Cuánto yo más quisiera ayer [en otras ediciones leemos convenien-

20 Gutierre Díaz de Games, El Victorial..., pp. 505-509, correspondiendo todo el episodio al Capítulo 67.

21 Sobre los posibles motivos de la redacción de las Andanzas, véase Pedro Martínez García, "Andanças e viajes: El otro Pero Tafur", Edad Media. Revista de Historia, 11 (2010), pp. 263-284.

22 Pero TAfur, Andanças e viajes..., pp. 18-19. 
temente 'aver'] caído en poder de los turcos que no ser anegado en tal lugar!" ${ }^{23} \mathrm{Al}$ menos siendo capturado por un infiel queda la esperanza de conservar la vida, de ser rescatado o incluso de morir como un mártir. La oscuridad marina representaba el peor de los finales posibles. En su tratado consolatorio, Enrique de Villena explica lo afortunado que es morir en la cama presentando una lista de formas de fenecer; pues bien, en este rosario de tipos de expiraciones, el que abre la tétrica serie es el ahogamiento: "¡Cuántos linajes de muertes escaparon con ésta! Pudieran en la mar tempestuosa periclitar e bever con la muerte las aguas saladas, devorados de los bestiales peçes, e con amaritut desçender al infierno..."24.

Añadamos a ello una nueva desgracia: a punto estuvo de ahogarse Tafur en el puerto de Quíos cuando la embarcación en la que estaba chocó con una carraca anegada por culpa del viento, partiéndose. Algunos marineros saltaron y fueron como pudieron hasta tierra, pero él tuvo que abrazarse a los maltrechos restos de la carraca y esperar a ser salvado por un grupo de vizcaínos que lo socorren con un esquife ${ }^{25}$. Por si todo esto fuera poco, tras superar otra tempestad cerca de Creta -usando además una expresión también empleada por Gutierre Díaz en similar contexto: casi desesperados de la vidapuede alojarse con un ermitaño unos días mientras se repara la embarcación. Nos deja una clarísima declaración de disgusto: "E si yo en tierra firme estuviera, según el miedo que avía pasado, para siempre nunca tornara a la mar" ${ }^{\prime 26}$. Las Andanças de Tafur son un relato fresco, de factura más libre. El estilo narrativo del caballero, infestado de un particular sentido del humor, trasluce como pocos documentos este tipo sentimientos e impresiones, rompiendo con la imitación y reelaboración de arquetipos.

A pesar de esta animadversión por el mar, Tafur sigue embarcándose. ¿Qué alternativas tiene? El transporte marítimo y fluvial no tiene sustituto para un hombre inquieto con la voluntad de conocer mundo o multiplicar su influencia social mediante el viaje. Mas Tafur ya no es el héroe que encarnaba Niño; escribiendo de sí mismo, cuenta lo que quiere, y su confeso humor le empuja a no censurar los pasajes que evidencian su fragilidad humana. Ciertamente en otras circunstancias el andaluz se desenvuelve con más nobleza, ni más ni menos que la propia para un hombre de su estado, y que afectan en especial a algunos pasajes vinculados a hechos de armas, permitiéndole recuperar el honor que parece perder en otros contextos. Las malas experiencias sufridas por el protagonista también lo son para aquellos que le acompañan, aunque no se deje ninguna pista de cómo padecen éstos tales vivencias, pues aparecen de una forma muy sucinta, sin identidad, irrelevantes e invisibilizados en el texto. Pero allí estaban.

También los marineros de Colón irradian miedo. De dominio público es el conato de motín que se gestaba a falta de pocos días para avistar tierra americana ${ }^{27}$. La navega-

${ }^{23}$ Ibíd, p. 116.

24 Enrique de Villena, "Tratado de Consolación”, Enrique de Villena. Obras Completas, ed. Pedro Manuel Cátedra García, Turner, Madrid, 1994, t. 1, p. 240.

25 Pero TAfur, Andanças e viajes..., pp. 120-121.

26 Ibíd, p. 163.

27 Cristóbal Colón, Diario..., pp. 27-34. 
ción mar adentro, fuera de los límites concisos del Mediterráneo o del cabotaje en la fachada europea atlántica, no dejaba de ser para la mayoría un viaje a ninguna parte por el Océano Tenebroso; lo que Al-Idrisi reflejara en su descripción de Hispania en el XII mantenía en parte su vigencia aún entonces ${ }^{28}$ :

\begin{abstract}
"Nadie sabe lo que hay en ese mar, ni puede averiguarse por las dificultades que oponen a la navegación las profundas tinieblas, la altura de las olas, la frecuencia de las tempestades, los innumerables monstruos que lo pueblan y la violencia de sus vientos. Hay, sin embargo, en este Océano un gran número de islas habitadas y otras desiertas; pero ningún marino se atreve a penetrar en alta mar, limitándose a costear sin perder de vista el continente. Empujadas hacia adelante las olas de este mar, parecen montañas y caminan sin romperse, y si no fuera por esto sería imposible franquearlas" ${ }^{\prime 29}$
\end{abstract}

La cuestión se agrava debido a que los marineros se percatan de que el viento no sopla hacia Levante, por lo que pierden progresivamente sus esperanzas en poder retornar a Europa, perdidos para siempre en un mar infinito. Aunque no le dedicaremos más líneas al asunto, la excesiva calma -ausencia de vientos- conlleva en altamar al menos tantos problemas como la tempestad. Es de sobra conocido que se consigue disciplinar a los marinos in extremis, y a los pocos días se alcanza tierra.

El temor que el Almirante expresa en su diario tiene una raíz distinta, sin perder de vista que de los textos seleccionados es el único creado por un marino de profesión. Colón manifiesta abiertamente su miedo durante el retorno, muy cerca de las Azores, pero no directamente por el hecho de la muerte en sí, sino por no poder dar relación de sus descubrimientos a Sus Altezas. Orgullo propio de quien desea demostrar su acierto en un ambiente que fue hostil a su hipótesis. Símbolo de ello es que, pese a la gravedad de la tormenta, documenta en un pergamino sus hallazgos, arrojándolo al mar en un tonel con la confianza de que alguien lo encuentre, sin que sus marineros sepan de qué se trata, pues escribe: "pensaron todos que era alguna devoçión" 30 . ¿Trataba de evitar que sus hombres se aterrorizasen aún más al ver a su guía perdiendo toda esperanza? Parece difícil que aquello pudiera haber alterado más sus ánimos, pero el Almirante tenía que demostrar estoicamente su liderazgo y fe en el triunfo de la misión. Eso refleja su diario, que contiene una buena dosis de fanática propaganda de sí mismo. Además, lamenta de manera explícita su posible fallecimiento por la idea de dejar a sus hijos huérfanos.

28 Acerca del cambio de percepción sobre el Atlántico a finales de la Edad Media, Eduardo Aznar VaLlejo, "Del mar soñado al mar hollado. El redescubrimiento del Océano", Cuadernos del CEMYR, 15 (2007), pp. 175-195. A ello contribuirá la conquista del archipiélago africano, relatada en Le Canarien.

29 Muhammad AL-EDRISI, "Descripción de España", Viajes de extranjeros por España y Portugal, ed. José García Mercadal, Junta de Castilla y León, Consejería de Educación y Cultura, Valladolid, 1999, t. 1, p. 171.

30 Cristóbal Colón, Diario..., pp. 162 y ss., correspondientes al jueves 14 de febrero de 1493. 
La tormenta marítima puede ir acompañada además de elementos adicionales (climáticosmeteorológicos y astronómicos), que aumentan su peligrosidad. El principal de ellos es la oscuridad de la noche, que desubica a los marineros y los arrastra en silencio, sin que se percaten, contra las peñas. Tormenta y noche forman un dúo que aterroriza, especialmente en el mar. Pero hay otros fenómenos menos frecuentes, que serían entendidos por su rareza como señales, por lo general, de mal agüero. Frente a la costa siciliana, Clavijo y los suyos "vieron descender del cielo dos ramos como de fumo que llegaron fasta el mar; e el agua subió por ellos tan aína, e tan rizio con grand roído, que las nubes inchió de agua e escuresció e anubló el cielo; e arredráronse con la carraca cuanto pudieron ca dezían que si aquellos ramos tomaran la carraca, que la pudieran anegar"31. Los de Colón "vieron caer del çielo un maravilloso ramo de huego en la mar, lexos d'ellos quatro o çinco leguas" "32. Pero Niño tiene que dar una explicación científica a sus hombres sobre un eclipse solar, pues quedan tan espantados que no quieren navegar más, al entender el suceso como un signo de terribles tormentas y muertes ${ }^{33}$. Este último es otro ejemplo de que ante la dificultad, el hombre común y la moderación se desvanecen y solo queda sitio para la heroicidad o la cobardía; situación, por cierto, proclive para destacar no solo la valentía, sino también las cualidades intelectuales de Niño, en este caso, una prestigiosa sabiduría astronómica.

Pero sin duda el incidente más impactante les ocurre a los embajadores enriqueños ${ }^{34}$. Se encuentran al norte de Sicilia en un momento borrascoso, que coincide con una erupción del Estrómboli y del Vulcano. Como es habitual, se dice, proceden a cantar la letanía. Después aparecen los fuegos de San Telmo - "una lumbre de candela"- en los mástiles, velas y antenas. Durante la noche, los marinos que están de guardia oyen unas voces de hombre junto al barco, quedando aterrorizados. Por si fuera poco, las "lumbres de Pero González de Tuy" (San Telmo, al que se habían encomendado) vuelven a hacer su aparición poco antes de que acabe la tormenta. En fin, todo un espectáculo del terror en el que no faltó de nada: tormenta, fuego, agua, electricidad y luces, presencia fantasmagórica, sonidos extraños. En esa función de la que no se puede escapar, el barco-teatro es a la vez escenario y palco, y sus ocupantes son actores y público. Con tal cadena de sucesos maravillosos, la sugestión y las estructuras mentales del momento (predisposición a ser beneficiarios de un milagro) hacen el resto. El final del episodio es feliz, con la desaparición de la oscuridad y de la tormenta retorna el codiciado buen tiempo seguro.

En última instancia quien lleva el timón es la providencia ${ }^{35}$. Hay que procurar navegar con pocos pecados acumulados o tener ganado el favor de alguna santidad, pues esa es

31 Ruy González de Clavijo, Embajada a Tamorlán..., p. 90.

32 Cristóbal Colón, Diario..., p. 23, correspondiendo tal visión al 15 de septiembre de 1492.

33 Gutierre Díaz de Games, El Victorial..., pp. 594-597.

34 Ruy González de Clavijo, Embajada a Tamorlán..., pp. 91-92.

35 En uno de los episodios del Libro del Caballero Zifar, Grima, mujer del protagonista, navega en una embarcación sin tripulantes, guiada por el niño Jesús - por ruego de Santa María- desde la vela. Se trata de otro milagro mariano muy similar a los narrados en las Cantigas de Alfonso X. No en vano, sobre el mar, a bordo de diferentes tipos de embarcaciones o en pequeñas urnas flotan imágenes de María o de Cristo 
la mejor garantía de alcanzar con suficientes garantías el puerto siguiente. El colectivo marinero -que nunca tuvo fama de observar debidamente los preceptos religiosossiempre puede optar a arrepentirse en el momento preciso. Se documenta una realidad sobradamente conocida, extrapolable a todos los ámbitos de la cotidianeidad medieval: la de las oraciones y las encomiendas, la de las romerías y los votos. Expresiones tales como "ya no valía allí remar, sino llamar a la Virgen Santa María para que nos acorriese, echar suertes para enviar un peregrino" o "no queda sino rezar" son frecuentísimas $\mathrm{y}$, así, los rudos lobos de mar se abandonan a los brazos de Dios amontonados en la sentina. Colón nos cuenta cómo se echaban a suertes con garbanzos a quien le correspondería ir de romero a tal o cual iglesia en caso de salvarse ${ }^{36}$; Gutierre Díaz también da cuenta de los votos que hacían "unos a Santa María de Guadalupe, otros a Santiago de Galizia, otros a Santa María de Finesterra, otros a Fray Pero Gonçález de Tuy, e otros a Sant Viçente del Cabo" ${ }^{37}$. Su cumplimiento se lo tomaban tan en serio como merece tomarse una promesa a la Virgen, a Dios, a los Santos; y así aparece constatado. Cuando la zozobra del navío se produce junto a la costa, siempre se cuenta con la ayuda desinteresada de los que están en tierra. La mejor que pueden ofrecer son los rezos, que repiten hasta que la contienda entre la tormenta y el buque se resuelve, pues, ¿qué otra cosa pueden hacer? En Cascaes estuvieron haciendo toda la mañana plegarias por la Niña hasta que los tripulantes consiguen encarar con la carabela la desembocadura del Tajo $^{38}$; un ermitaño reza por el barco en el que se encuentra Pero Tafur cuando lo ve en apuros desde la orilla cretense ${ }^{39}$. La carraca genovesa que acompaña a la comitiva de Clavijo se hunde al norte de Turquía, y salvándose su tripulación en barcas llegan a tierra; desde allí esperan a los de la galeota de Clavijo haciendo oración por ellos para que escapen, cosa que milagrosamente consiguen ${ }^{40}$. Imposible no recordar, al hilo de este último ejemplo, el milagro del náufrago salvado, composición magníficamente versada en cuaderna vía por Gonzalo de Berceo: los supervivientes de un naufragio rezan desde la orilla, viendo como del mar surgen palomas que se elevan al cielo - correspondientes a las almas de los difuntos-, pero también como un devoto de Santa María escapa con vida declarando haber sido salvado por el manto virginal por su firme creencia en el poder de la Madre de Dios ${ }^{41}$. La inclusión de estos benefactores anónimos en los relatos

esperando llegar a la costa o ser encontradas por navegantes; recordemos las leyendas de la Virgen de la Barquera, la Virgen del Mar o las más fascinantes del Santo Cristo de Burgos (vid. Ma José MARTínez MARTínez, "El Santo Cristo de Burgos y los Cristos dolorosos articulados", Boletín del Seminario de Estudios de Arte y Arqueología, 69-70 (2003-2004), pp. 210-211) y del Santísimo Cristo de las Claras de Palencia (vid. Manuel de CAStro, El Real Monasterio de Santa Clara de Palencia y los Enríquez, Almirantes de Castilla, Diputación Provincial de Palencia, Valladolid, 1982, pp. 57-60 y Real Monasterio de Santa Clara de Palencia. Apéndice Documental, Diputación Provincial de Palencia, Palencia, 1983, t. 2, pp. 143-156).

36 Cristóbal Colón, Diario..., p. 163.

37 Gutierre Díaz de Games, El Victorial..., p. 636.

38 Cristóbal Colón, Diario..., pp. 174-175, durante el lunes 4 de marzo de 1493.

39 Pero TAfur, Andanças e viajes..., p. 163.

40 Ruy González de Clavijo, Embajada a Tamorlán..., pp. 152-155.

41 Gonzalo de Berceo, Milagros de Nuestra Señora, ed. Fernando Baños, Crítica, Barcelona, 1997, pp. 132-139, Milagro XXII. En palabras de un magnífico medievalista francés, haciendo referencia a la Plena 
se puede entender como un signo de verdadero agradecimiento a su aportación decisiva para la supervivencia del protagonista en apuros. Además de mover montañas, la fe contiene, aplaca tormentas. Tengamos presente el pasaje evangélico en el que Jesús, con una palabra, hace enmudecer al lago enfurecido y borrascoso, recriminando a sus apóstoles su cobardía y falta de $\mathrm{fe}^{42}$. Esa es la lógica que domina, así en la tierra como en el mar.

En El Victorial, Gutierre Díaz abre un precioso diálogo con la Razón a causa de las tempestades y vientos marítimos, de los que se queja. La Razón vapulea al arrogante en estos términos:

\begin{abstract}
"Otrosí, bien sabes tú el honbre cómo lo crió Dios en la tierra, e en ella lo colocó; e los pezes e las aves, cómo las crio en la mar; e dio morada a los pezes el agua, e a las aves que corran por el ayre. Pues el honbre la tierra es su morada, e en ella puede aver su vito: ¿quién le dio a él fazer navíos, e fabricar argumentos contra natura para andar por la mar, pues que sin ella bien podría bivir? Forçado es que cada un elemento faga su ofiçio, e cumpla el misterio para lo que Dios le fizo. E si allí pereçe el honbre, suya es la culpa. Andar el honbre en la mar, contra natura es. Pues él demanda las cosas contra natura, razón es que cruelmente perezca"43.
\end{abstract}

Una manifestación simple y efectiva. El hombre es plenamente consciente de que el mar no es su medio, y atreverse a entrar en ese mundo impropio siempre es correr un riesgo innecesario ${ }^{44}$. Por eso, lo primero que hacen los marineros al pisar tierra es saltar del barco e ir prestos a cumplir sus votos y agradecer que se les haya escuchado y hecho merced. Se ha logrado evitar morir en el mar, sin opción a una digna sepultura y espacio de recuerdo del muerto para la comunidad de los vivos, cuestión que no es en absoluto trivial ${ }^{45}$. La fuerte religiosidad hace que todo viaje tenga un cierto componente de peregrinaje, pues los navegantes siempre tienen una promesa que saldar con quienes

Edad Media: "Ningún milagro está más extendido que el de la intervención de un santo para apaciguar una tempestad o resucitar a un naufrago", Jacques LE Goff, La civilización del Occidente Medieval..., p. 192. Al final, la creación de todos estos milagros se corresponde a una necesidad lógica, la de aplacar la desconfianza a embarcarse; por sumar otro ejemplo, aunque del S.XII, de los veintidós milagros obrados por Santiago y que se recogen en el Libro Segundo del Códice Calixtino, cuatro de ellos tienen por escenario el mar (VII, VIII, IX y X). Si volvemos la mirada a las mencionadas Cantigas y a las colecciones de ejemplos, encontramos también gran abundancia de ellos.

42 Este pasaje se encuentra en: Mc 4, 35-41, Mt 8, $23-27$ y Lc 8, 22-25.

43 Gutierre Díaz de Games, El Victorial..., pp. 613-614.

44 "Nunqua deuia omne en las mares fiar, / traen lealtad poca, seben mal solazar, / saben al reçebir buena cara mostrar, / dan con omne aýna dentro en mal logar". Corresponde a la estrofa 120 del Libro de Apolonio, ed. Dolores Corbella, Cátedra, Madrid, 1992, p. 113.

45 Sin salirnos de la obra anterior, en un momento dado Apolonio cree equivocadamente que su mujer ha muerto en el parto, y pese a que se niega a separarse de ella, el piloto le conmina a deshacerse del cadáver en altamar para garantizar la seguridad de toda la tripulación. La superstición afectaba de manera severa a una actividad que siempre es peligrosa. Finalmente lanzarán al agua un ataúd en el que dejan la siguiente inscripción: "Yo, rey Apolonyo, envio mercet pedir: / Quiquier que la fallare, fágala sobollir, / Lo que nol" pudiemos sobre la mar conplir". Ibíd, p. 166, estrofa 290. 
velan por ellos desde el más allá; esto no es un elemento exclusivo del asunto de la navegación, ya que encomendarse y establecer algún tipo de diálogo con la divinidad es casi obligado ante el emprendimiento de cualquier tarea cotidiana.

Dejando atrás las inclemencias del cielo que embravecen el océano, las mareas también suponen un riesgo. Nada más emprender el viaje, Pero Tafur se encuentra con el sitio de Gibraltar y decide retrasar su partida para ayudar a sus hermanos de religión. El asedio es un fracaso y, teniendo que retirarse los sitiadores en barcas por mar ante el acoso de los musulmanes y la subida de la marea, la del conde de Niebla vuelca y se ahogan él y los caballeros que lo acompañaban ${ }^{46}$. En El Victorial, con motivo de su llegada a Crotoy, Díaz se hace eco de una historia moralizante: un ejército inglés, que venía haciendo ofensiva por tierras francesas, aprovechando la bajamar descendió de sus barcos a tierra para saquear los lugares de la costa; hallando mucho vino, disfrutaron de una gran comilona junto a las naves, y sin acordarse de donde estaban, se quedaron dormidos en la bahía. Entonces llega la creciente y los sorprende, muriendo allí 600 hombres de armas, vencidos sin batalla. Obviamente aquí la marea es excusa, pues el vino es el verdadero protagonista de la desgracia, y se anota una invitación ejemplarizante a beberlo con moderación ${ }^{47}$. También en los Milagros de Gonzalo de Berceo encontramos a una mujer encinta que es sorprendida por la rápida subida de la marea cuando se dirige a la capilla de San Miguel, pero es salvada y da a luz sin dolor en el agua gracias a la Virgen ${ }^{48}$; este episodio, de gran difusión europea como tantos otros milagros que circulaban entonces, es graciosamente representado y miniado en las Cantigas $^{49}$.

\section{Y vi subir del mar una bestia que tenía diez cuernos y siete cabezas... ${ }^{50}$}

El mar es caldo de cultivo para episodios de hechicería, esconde seres espeluznantes o es en sí mismo un lugar tétrico, donde ocurren incidentes anormales. El mar son las tentaciones mundanas, "ca este mundo non es sinon mar perigloso, ca non podemos en él estar sin pecar" ${ }^{51}$. Asociado a la luna, a la noche, a la muerte, no sorprende que

\footnotetext{
46 Pero TAfur, Andanças e viajes..., pp. 12-13.

47 Gutierre Díaz de Games, El Victorial..., pp. 598-599. También en Las Siete Partidas del rey don Alfonso el Sabio..., t. 2, Partida II, Título XXIV, Ley IX, pp. 265-266, se habla de las viandas que se deben cargar en los navíos, mencionándose lo inconveniente de facilitar bebidas alcohólicas que mengüen las capacidades de los marineros, especialmente en campañas militares.

48 Gonzalo DE Berceo, Milagros de Nuestra Señora..., pp. 104-109, Milagro XIX

49 Alfonso X, Cantigas de Santa María, Códice T.I.1, Cantiga 86.

50 "Y vi subir del mar una bestia que tenía diez cuernos y siete cabezas, con una diadema en cada cuerno y un título blasfemo en cada cabeza". Ap 13, 1.

51 En estos términos se refiere al mar San Vicente Ferrer en su Séptimo sermón, en el cual expone una semejanza (similitudo) entre la travesía y la vida humana. La cita está extraída de Pedro Manuel CÁtedRA Garcí, Sermón, sociedad y literatura en la Edad Media. San Vicente Ferrer en Castilla (1411-1412), Junta de Castilla y León, Salamanca, 1994, p. 346. Otra semejanza, recurso muy empleado en la cultura narrativa de la Edad Media, la encontramos en las Partidas alfonsíes, donde se equipara al navío con el caballo (t. 2, Partida II, Título XXIV, Ley VIII, pp. 264-265).
} 
en sus abismos se perciba la alargada sombra de Satán. Veamos algunos fragmentos que abundan en la vertiente más intrigante del mar.

Niccòlo da Conti, un viajero italiano con el que Tafur supuestamente ${ }^{52}$ tiene el placer de compartir unas jornadas de travesía, le cuenta que en las tierras del mítico Preste Juan el arte de la nigromancia es habitual, y que navegando por el mar Bermejo vio desde la vela hasta abajo descender y subir un "bulto negro" muchas veces, hasta que lo detienen y le preguntan sobre su destino. Y este bulto (rostro) responde: "avrés seis días de calma muerta, que la mar estará como astite e el navio no fará camino, e aparejad, que avrés otros tantos de muy afortunada tormenta" "53. Conviene no olvidar que el Preste y su gente son buenos cristianos y, pese a su aislamiento entre infieles, un modelo a seguir. Su empleo de métodos peligrosos y mágicos, vedados por lo general, se excusa en un alejamiento cultural que altera sensiblemente los valores y conductas permitidos.

Por su parte, Pero Niño sufre una turbonada frente a Málaga, a la que inexplicablemente se le da un origen mágico, teniendo en cuenta que es un fenómeno bastante común en la zona y presumiblemente conocido por la tripulación experimentada que lo acompañaría. Estando la mar en calma a mediados de mayo y con cielo claro, se levantó a deshora una niebla muy oscura, cayendo sobre las galeras de manera que los de una no veían a los de la otra, pese a la cercanía. Algunos marineros -a los que se toma por autoridad en el relato- que lo habían visto otras veces dijeron que "los moros eran fechiçeros de aquellas tales cosas, e que ellos lo farian a fin si pudiesen fazer perder las galeas" Los marineros hacen la señal de la cruz y oraciones para librarse de aquella maldad pronto. Frente a esa magia diabólica del infiel, se contesta con una invocación cristiana de esencia no menos mágica, que desencadena el milagro. Y así fue, que "súbitamente se deshace y se torna en nada", apareciendo el tiempo claro. La divinidad verdadera se impone sobre la falsa deidad del enemigo, enérgicamente maligno, pues no es otro que el Demonio, pero nunca tan poderoso.

También El Victorial se hace eco, en la larga leyenda de Bruto y Dorotea, de la aparición de una gigantesca flota fantasmagórica invocada por ella mediante la nigromancia para vencer a los africanos que bloqueaban su camino; los enemigos huyen al verla llegar pensando que se trata del ejército naval de Bruto en socorro de su esposa. Una vez vencidos, la flota se va tornando en bruma hasta que se evapora, ante el asombro generalizado de la propia tripulación de Dorotea, que también había caído en el engaño ${ }^{55}$. Las profundidades marinas no están accesibles a ningún hombre, exceptuando, claro, al prototipo de caballero andante, Alejandro, que descendió al océano en un arca de cristal y

\footnotetext{
52 Decimos supuestamente dado que las investigaciones han planteado la oportuna duda sobre si realmente se conocieron, teniendo en cuenta las sensibles diferencias entre lo que Conti habría contado a Tafur y lo que relató a Poggio Bracciolini, secretario apostólico de Eugenio IV.

53 Pero TAfur, Andanças e viajes..., p. 103. Aunque no es el caso que nos ocupa, entre quienes tenían un difuso conocimiento del Mar Rojo estaba asumido el hecho de que sus aguas tenían el color de la sangre, como queda documentado en textos y cartografía variada.

54 Gutierre Díaz de Games, El Victorial..., p. 381.

55 Ibíd, pp. 475-476.
} 
permaneció allí recibiendo pleitesía de los monstruos marinos, para resucitar de las aguas a los tres días ${ }^{56}$. Aún hoy sigue siendo el último confín inexplorado y la especulación sobre sus moradores a lo largo del tiempo ha sido infinita; imaginemos una sociedad que desconocía prácticamente todo lo que se encontraba bajo los primeros metros de superficie. Los océanos además separan el escenario maravilloso, son la frontera insalvable e infinita, se interponen entre el hombre medieval y aquello a lo que nunca podrá acceder pero que por fuerza tiene que existir: territorios donde viven los cinocéfalos y los monóculos, archipiélagos controlados por las amazonas, islotes hechos de oro, el reino del Preste Juan, la canaria isla de San Borondón, una patria de longevos humanos que disfrutan de una vida sin enfermedad hasta su muerte a los 300 años... Es un confín perfecto que posibilita la alteridad en su máximo esplendor, pues siempre hay un más allá inubicable o móvil, aspectos que la tierra firme no puede ofrecer con tantas garantías.

Pues bien, en estos abismos se esconden alimañas que de vez en cuando se dejan sentir $^{57}$. Según Tafur, en Espalato (Split, en la actual Croacia) las mujeres desaparecían sospechosamente cuando hacían sus labores en la orilla del mar. Un día, un monstruo, de cintura abajo en forma de pez y con la parte superior humana pero con alas semejantes a las del murciélago, captura a una mujer y la arrastra al fondo del agua, siendo socorrida por quienes estaban cerca; con mucho esfuerzo la consiguen liberar de las garras de la bestia y capturan al monstruo. Cuando muere, lo abren, lo salan y lo envían a la Señoría de Venecia para que a su vez se lo hiciese llegar al papa Eugenio. Excéntrico presente pontifical. "Esto yo no lo vi, pero dicho me fue e que avía poco que avia acaecido" 58 , aclara Tafur, sumando motivos para mirar con suspicacia al mar. Curiosamente, esta monstruosidad comparte los rasgos de las sirenas aladas y de las marinas. Más tarde, cuando está de regreso a Castilla, se hace eco al pasar por Mesina de que tal lugar es donde los poetas clásicos sitúan a las sirenas -recordemos la Odisea de Homero $^{59}$-, esas a las que si se escucha cantar durante una tormenta es porque la muerte está casi garantizada ${ }^{60}$. Acordémonos de los vigías que navegaban con Clavijo y que por esos mismos mares oyeron voces al lado del barco durante la tormenta; sin embargo se especificaba que esas voces que los alertaron eran "como de omnes" 61 . Es difícil no recordar al hilo de estas experiencias el Romance del Conde Arnaldos ${ }^{62}$, en

\footnotetext{
56 Ibíd, p. 237. Como bien se ha indicado, en el Libro de Alexandre esta "conquista del agua" se une a su dominio sobre la tierra, su viaje por el aire (volando en un carro movido por grifos) y a su voluntad de descender al infierno (fuego), señoreando así los cuatro elementos.

57 Para una mejor comprensión del papel simbólico de estos seres, atiéndase a Nilda GugLIELMI, El Fisiólogo: Bestiario Medieval, Eneida, Madrid, 2002 e Ignacio MalaXeCheverría, Bestiario medieval, Siruela, Madrid, 2000. En cuanto a la representación y a la presencia escultórica de los mismos en Castilla, Jesús Herrero Marcos, Bestiario Románico en España, Ediciones Cálamo, Palencia, 2010.

58 Pero Tafur, Andanças e viajes..., p. 165.

59 Las encontramos concretamente en el Canto XII de esta obra, donde también aparecen las temibles Escila y Caribdis.

60 Pero TAFur, Andanças e viajes, p. 248.

${ }^{61}$ Ruy González de Clavijo, Embajada a Tamorlán..., p. 92.

62 Antología. Romancero S. XV, ed. Federico Carlos Saínz de Robles, S.A.P.E. Club Internacional del Libro, Barcelona, 1986, p. 199.
} 
el cual un noble, mientras caza, es seducido por una canción que entona un marinero desde una embarcación cercana a la orilla, la cual solo reserva a quién con él viaje; parece deducirse del misterioso relato que este nuevo Caronte le estaría ofreciendo a Arnaldos elegir entre la vida y la muerte.

En la Isla de la Española (Santo Domingo) el Almirante reseña haber visto tres sirenas que salieron a flote, pero no eran tan hermosas como las pintan, que en alguna manera tenían forma de hombre en la cara $^{63}$. Mantiene una total naturalidad al hablar de esas falsas sirenas, que no serían sino manatíes. Al fin y al cabo, en el contexto del descubrimiento de todo un Paraíso Terrenal, como se refiere él a las tierras alcanzadas, una sirena era un hallazgo menor y además, no inédito para Colón, pues anota que las pudo ver también en otras ocasiones en Guinea. También se menciona a las sirenas -peces muy extraños- en Le Canarien ${ }^{64}$, vinculando su vista con la inmediatez de una tormenta. Enrique de Villena, en Arte Cisoria, tratado sobre el arte de cortar el cuchillo, también se deja seducir por la tradición que hace de la sirena la reina del mar: "maguer algunos digan que la serena con ella [con la ballena] se eguale en grandes, pero non se toma nin comen d'ella"65. Y es que, como expone Navarro González, "las «serenas» son el mito marinero que más abundantemente aparece en la literatura castellana" ${ }^{\text {. }}$

Si volvemos a centrarnos en El Victorial, en uno de los muchos momentos en los que se interrumpe la narración cronística-biográfica -en esta ocasión para explicarnos porqué Inglaterra significa tierra de maravillas - nos encontramos un episodio legendario de interés. Se sucedieron en esta isla - dice- años muy menguados de aguas, tanto que la tierra se tornó estéril y no dio frutos; por eso se produce una gran mortandad y los hombres tienen que dejar la tierra y buscar otra más fértil. El rey capitanea una emigración masiva a la Bretaña francesa y pueblan el lugar. Durante ese reinado sucede que sale de la mar "una serpiente muy fiera e grande, e mucho espantable. Avía el cuerpo fechura de pescado, e la boca e pico como águila, e piernas e uñas como león, e alas como ave. E llamávanla belva [fiera] marina. E tenía cueva en la tierra, cerca de la mar"; este ser se movía indistintamente bajo o sobre el mar, mientras que en tierra mataba a hombres y ganado y los devoraba en su cueva, donde se amontonaban los huesos (nótese la coincidencia con el dragón al que da muerte San Jorge, que también vivía en las inmediaciones de un lago ${ }^{67}$ ). Muchos hombres trataban de darle caza, pero escapaba siempre. Así que el rey escoge a doce caballeros bravos (número lógicamente no casual ${ }^{68}$ ), expone su emotivo discurso y se dirige a la caverna. Dará muerte él mismo

${ }_{63}$ Cristóbal Colón, Diario..., p. 142, durante el miércoles 9 de enero.

64 Gadifer DE LA SAlLe, Le Canarien, crónicas francesas de la conquista de Canarias, ed. Elías Serrá y Alejandro Cioranescu, Instituto de Estudios Canarios, La Laguna, 1959-1965, t. 3, p. 124.

${ }^{65}$ Enrique de Villena, "Arte Cisoria”, Enrique de Villena. Obras Completas, ed. Pedro Manuel Cátedra García, Turner, Madrid, 1994, t. 1, p. 186.

66 Alberto Navarro Gonź́lez, El mar en la literatura medieval castellana..., p. 218.

67 Jacobo De La Vorágine, La Leyenda Dorada, ed. José Manuel Macías, Alianza Forma, Madrid, 1990, pp. 248-253. Las páginas se corresponden al capítulo LVIII, dedicado a San Jorge.

68 Solo un ejemplo: Juan II celebra unas fiestas en Valladolid en 1428, representando a Dios Padre y rodeado de doce caballeros simbólicamente bien ataviados que a su vez emulaban a santos mártires. Vid. Pedro 
a la fiera porque sus elegidos muestran gran pavor en la hora decisiva, falleciendo a su vez debido a las heridas causadas por la bestia. Pasado algún tiempo, llueve mucho en Inglaterra, volviendo a hacerse la tierra abundante y libre de enfermedades, por lo que el pueblo emigrado puede retornar a su tierra originaria ${ }^{69}$. Aquí es interesante, aparte de la leyenda del monstruo marino en sí, el ciclo mítico que se abre y concluye con el agua de la lluvia, en escasez y en abundancia.

Hay otros animales curiosos que pueblan los mares. Por ejemplo, Niccòlo da Conti relata a Tafur la existencia de unos cangrejos que al salir a la arena de las playas y recibir el aire se convierten en piedra ${ }^{70}$. Otros parecen más peligrosos, como el pejerrey, que según El Victorial, basándose en la desconocida Crónica de los Reyes de Inglaterra, es un pequeño pez que vive en las costas inglesas, hallado en muy pocas ocasiones; ocurre que si lo matan por error, durante tres años en la costa en la que muere no se podrá pescar pescado alguno, ni grande ni pequeño, y todos los mares serán escasos durante ese tiempo. Por eso cuando los hombres encuentran un pejerrey lo devuelven al mar para que viva ${ }^{71}$ ¿ ¿No evoca esto un clarísimo temor a perder la abundancia de los frutos del mar en un país volcado al océano? Tampoco faltan seres reales que producen asombro similar a las bestias imaginadas, como las ballenas o los peces voladores. Admiración y desconfianza a partes iguales, por tanto, al calibrar los súbditos inesperados del mar.

En definitiva, si hacemos recuento de maravillas acuáticas, ninguno de nuestros personajes ha visto ninguna, a excepción, claro está, de los manatíes colombinos, que ni tienen aspecto humano ni poseen habilidades dignas de mención. Su presencia está siempre sugerida por cuentos, rumores o lecturas que no se han podido avalar directamente con los sentidos. Siquiera Clavijo, que es un concienzudo detallista, da más referencias sobre las voces espectrales que, en cualquier caso, escucharon otros. Algunos autores han venido destacando la escasez de florituras maravillosas e imaginería en las obras hispanas, tendentes al realismo, en comparación siempre con las producciones del espacio geográfico ultrapirenaico, árabe y oriental ${ }^{72}$. Sin embargo, encuentran su hueco en los textos y alimentan la imaginación fantasiosa en el consumidor de la obra. Se alzan como un elemento ineludible, un ingrediente si se quiere, de la historia. La cartografía va expulsando desde el centro hacia los márgenes las imágenes de monstruos que por tradición poblaban los mapamundis ${ }^{73}$, pero se les reserva un espacio preferente en la literatura que prevalecerá aún durante mucho tiempo debido a la demanda y al peso de la tradición.

Además hay mares en los que directamente es mejor no entrar, porque son en su propia esencia destructivos. Tal es el caso particular del Mar Muerto. Tafur se permite el lujo de

Carrillo de Huete, Crónica del Halconero de Juan II: hasta ahora inédita, ed. Juan de Mata Carriazo, Espasa-Calpe, Madrid, 1946, pp. 24-26, cap. VI.

69 Gutierre Díaz de GAMEs, El Victorial..., pp. 640 y ss. Encontramos este episodio proveniente según el autor de la Corónica de los Reyes de Angliaterra, documento que nos es absolutamente desconocido.

70 Pero TAfur, Andanças e viajes..., p. 99.

71 Gutierre Díaz de Games, El Victorial..., pp. 639-640.

72 Por citar un clásico, "[los romances de tema nacional] no gustan de ningún elemento maravilloso". Ramón Menéndez Pidal, Romancero Hispánico, Espasa-Calpe, Madrid, 1953, t. 1, p. 266.

73 Paul Zumpthor, La medida del mundo..., pp. 161-162. 
hacer una excursión en solitario con "un moro", al que le pide que le guíe más allá del Jordán. Pasan por el Mar de Pentápolis (nuestro Mar Muerto), que baña las ancestrales ciudades que fueron subvertidas por el pecado de la sodomía; es el agua tan hedionda que no permite la presencia de pescado, infecta incluso para las aves, que no se atreven a posarse en ella. Su guía le cuenta una maravilla: el río Jordán entra y sale del piélago sin mezclarse con el agua corrompido, e incluso en medio del mismo se podría beber el agua dulce del río ${ }^{74}$. También en los viajes del Infante Don Pedro de Portugal, narración de unas travesías que no tuvieron lugar (no es algo excéntrico, recordemos el célebre libro de los Viajes de Mandeville o el Libro del Conocimiento) en una obra de autoría discutida entre castellanos y portugueses, se habla así de los alrededores del Mar Muerto, concretamente de Sodoma y Gomorra: "e fuemos por ver estas ciudades que están fechas lagos de agua negra y el agua está llena de carvones y dizen que son la generación que se perdieron, [...] y si hombre toma un palo o una paja lançándola en los lagos, luego se hunde, y si echa una piedra o hierro, anda sobre el agua contra natura"75. Esta anomalía se ha interpretado como un símbolo de la inversión moral que representaban estas ciudades ${ }^{76}$. Por otra parte, cambiando de latitudes, en la Embajada a Tamorlán se explica que en el Océano Índico, concretamente en el Golfo Pérsico, los navíos son únicamente de madera y cuerdas, sin poder llevar hierro alguno, puesto que en ese caso serían deshechos por las piedras imanes que abundan en aquel mar ${ }^{77}$.

Otros secretos horrorosos se esconden bajo el agua, algunos de raíz plenamente humana, aunque sea la mano diabólica la que empuja a tales atrocidades: en las Andanzas se explica cómo era frecuente que los pescadores venecianos sacaran fetos con sus redes; esto ocurría por las largas ausencias de los mercaderes y la propensión a la infidelidad de las mujeres, que quedan embarazadas de otro hombre y que, por guardar su fama, tras dar a luz echaban las criaturas por las ventanas a la $\operatorname{mar}^{78}$. Felizmente, las autoridades actuarían construyendo un hospital para evitar los crímenes y cuidar a estos infantes. En este caso, el mar domesticado que son los canales venecianos sirve de guarida al infanticidio y la lujuria, se traga los pecados de los humanos. Aquí el agua no es simplemente un complemento circunstancial de lugar, sino que es un factor que incita a la mujer, debido a su sospechado débil carácter, a delinquir bárbaramente; ejerce de tentación.

\section{Los riesgos del agua más allá del mar}

Los ríos también dan lugar a toda una serie de contingencias. Quienes no tuvieron ocasión de conocer el mar más que a través de terceros, al menos tuvieron la oportunidad de

\footnotetext{
74 Pero TAfur, Andanças e viajes..., pp. 67-68.

75 Gómez De Santisteban, Libro del infante don Pedro de Portugal, ed. Elena Sánchez Lasmarías, Memorabilia, 11 (2008), p. 20.

76 A este respecto, véase Francis Millet Rogers, The travels of the Infante dom Pedro of Portugal, Harvard University Press, Cambridge (MA), 1961, p. 185.

77 Se narra esta leyenda en Ruy GonzÁlez de Clavijo, Embajada a Tamorlán..., p. 207.

78 Pero TAfur, Andanças e viajes..., p. 184.
} 
sentir la furia de las venas que lo alimentan. El poder transformador de los ríos sobre el paisaje y los dominios de los hombres queda recogido incluso en las leyes alfonsíes, que prevén las modificaciones de superficie de las haciendas por la fuerza del agua ${ }^{79}$. También fuentes cronísticas, como la del Halconero, destacan las riadas producidas por tormentas espeluznantes y el escenario de desolación a su paso ${ }^{80}$. Clavijo nos habla de la destrucción de algunas villas persas debido al amplio caudal que alcanzan los ríos cuando la nieve de las montañas se derrite ${ }^{81}$. En otra ocasión, al paso de la comitiva por Damhgan (Irán) se vive un tiempo insufrible; por lo visto, se debe a que en una sierra que había cerca de la ciudad se encontraba una fuente y que, cuando algún animal o cosa sucia caía en ella estallaba el mal tiempo, que no cesaba hasta que limpiaban aquella poza ${ }^{82}$.

A punto está de perder la vida el rey Enrique III en el Guadalquivir mientras descendía con su barca hacia Sevilla en medio de una fuerte corriente, pues había una gran maroma de pesca de lado a lado del río, mas Pero Niño está raudo y de un espadazo corta la cuerda. Los marinos se maravillan por la habilidad de Niño, que ha salvado a la embarcación de enredarse y volcar, y a ellos probablemente de la muerte ${ }^{83}$. Ningún río es seguro; ni siquiera cuando uno cree estar en un éxtasis religioso se halla a salvo; con motivo de la visita al lugar bíblico de San Juan Bautista en el Jordán proceden a bañarse todos los peregrinos y entonces, dice Tafur, "se nos afogó aquel día un cavallero de Alimaña"84. Igual suerte tuvo el emperador Federico I, ahogado en desconocidas circunstancias en el río Göksu cuando dirigía a sus cruzados a Tierra Santa. El andaluz queda también muy impactado con el Nilo, en el cual hay unas bestias -cocatrices o cocodrilos- extremadamente peligrosas, pero que huyen del búfalo; por eso, como no hay puentes, los cairotas cruzan el río a lomos de éstos. Dice Tafur que en el Nilo nadie osa tomar agua con su mano, sino que atan una vasija en un asta. Llevan en las barcas continuamente tres atabales, uno a popa, otro a proa y otro a medianía, con el fin de espantar a los cocodrilos. Asimismo le describen otros moradores del río, los cuales no llega a contemplar: los hipopótamos. Sin embargo, el agua de este río le parece del Paraíso, y en el tiempo en que nuestro viajero está en sus orillas no hace sino beber de allí, "pudiendo beber buen vino"85.

Aunque el río Nilo, habitualmente considerado como uno de los cuatro del Paraíso, esconde otros misterios: Niccòlo da Conti cuenta a Tafur cómo el Preste Juan quiso conocer la procedencia de estas aguas. Para ello mandó a hombres en barcas a remontar la corriente, pero anduvieron tanto que se quedaron sin vituallas y tuvieron que volver. El Preste Juan, lejos de abandonar su deseo, preparó a niños criándoles a base de pescado

\footnotetext{
79 Las Siete Partidas del rey don Alfonso el Sabio..., t. 2, Partida III, Título XXVIII, Leyes XXVI - XXXII, pp. 719-722.

80 Pedro Carrillo de Huete, Crónica del Halconero de Juan II..., pp. 182-195, cap. CLXXVIII.

81 Ruy González de Clavijo, Embajada a Tamorlán..., pp. 222 y 240.

Ibíd, p. 329.

3 Gutierre Díaz de Games, El Victorial..., pp. 338-339.

84 Pero TAfur, Andanças e viajes..., p. 67.

85 Ibíd, pp. 79-80.
} 
crudo y cuando fueron lo suficientemente maduros, les dio barcas y redes de pesca para la misión y les ordenó que no volviesen sin traerle una respuesta satisfactoria sobre el origen del río. Pasaron por muchas tierras, hasta que llegaron a una enorme sierra de la cual bajaba el agua. Subieron lo más que pudieron a ella para encontrar el nacimiento, pero los que ascendían hasta el aparente nacimiento no retornaban ni contestaban a las llamadas de los que quedaban abajo. Como vieron que era un misterio que no podían resolver, se volvieron y contaron al Preste lo que habían hallado, diciéndole que no debía desear saber más, puesto que a Dios no le placía que los mortales conociesen tal cosa, y por eso había encerrado allí a los más osados ${ }^{86}$. El Paraíso Terrenal -como el Celestial, oficialmente solo visitable por los vivos en sueños, éxtasis, desdoblamientos y visiones místicas - también está vedado. Durante siglos se ha alimentado la imagen en la que el sagrado lugar se encuentra tras montañas infranqueables o muros ígneos en algún lugar incógnito de Asia, pero esta tradición ha convivido con otra, de raíces célticas: la de los immrama que hablan de islas paradisiacas emplazadas hacia Occidente ${ }^{87}$. Más allá de los ejemplos estudiados, en El Corbacho la corriente fluvial arrastra a una mujer respondona, a la que ha arrojado un marido despechado en un ataque de ira ante

\footnotetext{
${ }^{86}$ Ibíd, pp. 100-101. Existe una amplia coincidencia con las características del Paraíso Terrenal que se exponen en el Libro del Conocimiento, imaginario libro de viajes del XIV que integra un amplio armorial: Vid. Libro del Conosçimiento de todos los reynos et tierras et señoríos que son por el mundo et de las señales et armas que han cada tierra et señorio por sy et de los reyes et señores que los proveen, ed. Marcos Jiménez de la Espada, El Albir, Barcelona, 1980, pp. 64-66.

87 Además de la aventura célebre de la Navigatio Sancti Brandani, que sería bien conocida en la Península, tenemos el ejemplo de una obra datada varios siglos antes del que nos ocupa: el fantástico viaje y estancia de Trezenzonio en la isla paradisiaca de Solistición, situada frente a La Coruña. La misma estaba cubierta de una espesa niebla, y solo se revelaba su ubicación a los elegidos mediante un espejo colocado sobre la Torre de Hércules. Este relato se recoge en Manuel C. Díaz y DíAz, Visiones del más allá en Galicia durante la Edad Media, Bibliófilos Gallegos, Santiago de Compostela, 1985, pp. 95-119. Otro de estos viajes hacia el Paraíso Terrenal, del que tenemos un manuscrito castellano en el XV, será el realizado por San Amaro. Atraviesa con sus acompañantes diversas islas viajando hacia el Este, donde les ocurren un buen número de sucesos maravillosos, entre las cuales no falta el enfrentamiento con "bestias fuertes marinas (...) grandes así como cavallos, e mayores", devoradoras de carne humana y vencidas gracias a la intervención mariana. Estudio y texto en Carlos Alberto Vega, Hagiografía y literatura. La vida de san Amaro, El Crotalón, Madrid, 1987. Apuntemos también el relato del viaje del bohemio León de Rosmithal de Blatna por la Península Ibérica entre 1465 y 1467. En él, uno de los cronistas se hace eco de una leyenda, recogida en los anales de la historia, que narra cómo tres navíos partieron de Portugal en una misión de exploración. Después de padecer numerosos contratiempos y encontrar unas islas llenas de metales preciosos entre la niebla y las olas, solo una de las embarcaciones retornó, perdiéndose las otras dos. A su vuelta, nadie les reconocía como los marineros porque habían envejecido con una rapidez inusitada; se repite el tópico del desdoblamiento del tiempo, solo que en esta ocasión se invierte la tendencia general (encontrada en Trezenzonio o San Amaro) al ser quienes emprenden el viaje maravilloso los que sufren una aceleración de su desarrollo vital y ralentizarse el tiempo entre quienes se quedan. Vid. "Viaje del noble bohemio León de Rosmithal de Blatna por España y Portugal. Hecho del año 1465 a 1467", Viajes de Extranjeros por España y Portugal..., t. 1, pp. 261-262, que se corresponden con la relación hecha por SHAscheK. Por último, y a fin de no excedernos en el asunto de navegaciones hacia lugares fantásticos o paradisiacos, recordemos que en el Zifar hay dos travesías a reinos maravillosos, donde las normas del mundo conocido no rigen: uno se encuentra en el tétrico lago Solfáreo, a donde va el caballero Atrevido; el otro son las Islas Dotadas, espacio de destierro de Roboán.
} 
tal porfia ${ }^{88}$. Si viajamos al siglo precedente, encontramos en la genial obra de don Juan Manuel un río que se traga a un codicioso, incapaz de soltar las pesadas joyas que le hacen hundirse, pese a las recomendaciones del ya clásico espectador que desde la orilla le espeta que pierda la fortuna para al menos salvar la vida ${ }^{89}$. También ocupa un lugar común entre las historias moralizantes el clérigo lujurioso que abandona el monasterio en la noche para cortejar a damas, sucumbiendo en la corriente, pero resucitado después por su devoción sincera a la Virgen; o el niño que mientras juega cae al arroyo -o es arrastrado por una ola al estar cerca de la orilla-y goza de la misma suerte. Como vemos, no solamente el mar es cementerio de pecadores. La legislación alfonsí también prevé para delitos de especial gravedad el ahogamiento en ríos; el culpable era enfundado en un saco -con "un can, et un gallo, et una coluebra, et un ximio" en su interior-y lanzado a la corriente fluvial más cercana ${ }^{90}$.

Volviendo al siglo XV, en la enorme recopilación de exempla de Clemente Sánchez de Vercial, se recoge uno bajo el título de Aqua justos et santos eciam reveretur, romanceado como El agua cara reverencia / a los justos de buena conciencia ${ }^{91}$. En él se hace eco de uno de los capítulos de los Diálogos de San Gregorio, en el que se narra como el río Adigio, a su paso por Verona, se desborda; crece tanto que llega a la iglesia de San Zenón, pero el agua la envuelve, elevándose ante la puerta como si fuera un muro líquido, sin penetrar en ningún momento al recinto sagrado. Independientemente de si es el poder del santo el que detiene el agua o es el agua el que se refrena para humillarse ante el santo, el resultado es el mismo: respeto a la morada del santo y a la vida de todos aquellos devotos que habían buscado refugio en el lugar ante la inundación, quienes certifican el milagro. Una nueva evidencia de que el poder destructor del agua es selectivo, y se mueve, como el resto del universo medieval, en torno a los parámetros religiosos.

El agua no es solo peligrosa en su estado líquido; es igualmente letal en forma de hielo y nieve. Pero Tafur, que recorre el Centro de Europa durante la estación fría, da buena fe de ello. En Los Alpes, cruzando por un puerto de montaña en un trineo tirado por bueyes, nos dice que cuando se cruza por angosturas donde hay grandes alturas y montañas de nieves en deshielo, abren fuego con unas culebrinas para que el estruendo haga caer la nieve que está más despegada; "e ya ha acaecido, pasando la gente, despegarse la nieve e matallos" "92. Además, los ríos pueden arrastrar enormes bloques de hielo que destruyen edificios ${ }^{93}$ (puentes, molinos y casas). Incluso éstos pedazos de hielo pueden tener propiedades mágicas, ejerciendo de prisión de un alma castigada por pecados pendientes del perdón, como ocurre en uno de los exempla de la recién citada colección de Sánchez

88 Alfonso Martínez de Toledo, El Corbacho, ed. Joaquín González Muela, Castalia, Valencia, 1970, pp. 153-154. Corresponde con la Parte II, Capítulo VII: Cómo la mujer es desobediente.

89 Juan Manuel, "El conde Lucanor", Obras Completas don Juan Manuel, eds. Carlos Alvar y Sarah Finci, Fundación José Antonio de Castro, Madrid, 2007, pp. 832-834, Ejemplo XXXVIII.

90 Las Siete Partidas del rey don Alfonso el Sabio..., t. 3, Partida VII, Título VIII, Ley XII, p. 571.

91 Vid. Clemente SÁnchez de Vercial, Libro de los exemplos por A.B.C., ed. M a del Mar Gutiérrez Martínez, Memorabilia, 12 (2009-2010), pp. I-VII. Exempla 31.

92 Pero TAfur, Andanças e viajes..., p. 195.

93 Ibíd, p. 196 
de Vercial; el ánima solo escapa al convertirse el bloque helado en agua líquida gracias a una treintena de misas ${ }^{94}$ (treintanarios instituidos por San Gregorio). También Clavijo relata una enorme nevada que les impedía andar: llevaban 30 hombres nativos con palas delante de la comitiva que les iban abriendo camino hasta el siguiente pueblo. La nieve les cegaba e impedía que encontraran las rutas, e incluso que los guías reconociesen por donde pasaban ${ }^{95}$. Encontramos muchos otros episodios de ríos y puertos congelados que dificultan la navegación durante las estaciones frías y que conllevan peligros, pero por ahora consideramos innecesaria su referencia por ser redundantes sobre lo ya expuesto.

Por último, el "no-agua" también supone un problema que se recoge en estas obras, y que conocemos bien en otros contextos, por ejemplo en el de la piadosa lucha contra las sequías. En el Sinaí, en los desiertos asiáticos de camino a Samarcanda o a bordo de un navío, morir de sed es una realidad que persigue al viajero más intrépido. Incluso en algunas ciudades no es nada recomendable beber el agua disponible por su escasa salubridad. Así que como un negativo de la fotografía del miedo al agua, en la que un ahogamiento rápido ya no parece la peor de las muertes posibles, emerge la horrible perspectiva de desvanecerse deshidratado tras una larga agonía. La extrema aridez, como la inundación, también se escapa de la virtud de la templanza en la naturaleza y por su peligrosidad llama la atención y merece destacarse.

Los embajadores, después de varias etapas por Asia Central en las cuales se va apuntando la sequedad de las tierras y la ineludible necesidad de andar durante la noche para evitar los calores extremos, llegan a un suceso dramáticamente narrado: se quedan sin agua que beber, los caballos apenas pueden moverse sobre el terreno arenoso y mueren; finalmente un mozo joven, que conservaba un buen caballo, se adelanta hasta un río, en el que moja sus camisones y vuelve a la comitiva de embajadores, ya cerca del desmayo, para que beban de los ropajes empapados. Héroe anónimo, salva la vida a todos ${ }^{96}$. Pero Tafur está más preparado cuando cruza el desierto en dirección al Sinaí; en su caravana llevan una buena provisión de té y de líquidos ${ }^{97}$. El fuerte viento, enemigo en la mar, lo es igualmente en el desierto, moviendo las dunas de arena y modificando el paisaje, provocando en los guías desesperación al no hallar el camino, tal como ocurría a los orientadores de Clavijo por la nieve.

Incluso estando rodeado de agua no se garantiza la supervivencia. Pero Niño en su campaña mediterránea es obligado varias veces a enviar a sus hombres a aguadas en la costa norteafricana, poniéndolos en grave peligro por las emboscadas de los enemigos, que custodian estos puntos estratégicos. Tienen que racionar el agua, entrando en esta regla todos, incluyendo al capitán ${ }^{98}$. En el caso de Colón, las grandes lluvias que había en el Caribe y lo caudaloso de sus ríos no dan lugar a episodios de sed, abundando los elogios a esas aguas cristalinas que consideraba como descendentes del Paraíso.

94 Clemente Sánchez de Vercial, Libro de los exemplos por A.B.C...., Exempla 28.

95 Ruy González de Clavijo, Embajada a Tamorlán ..., pp. 330-331.

96 Ibíd, pp. 234-235.

97 Pero TAFur, Andanças e viajes..., p. 91.

98 Gutierre Díaz de Games, El Victorial..., p. 425. 


\section{Consideraciones finales}

En definitiva, después de este recorrido por algunas de las referencias que encontramos en las fuentes citadas, queremos resaltar dos cuestiones. Primero, el miedo cambia, es profundamente humano y por tanto es irreprochablemente historiable. La sociedad atravesada por una serie de temores modifica sus concepciones y sus comportamientos en función de sus inquietudes; entonces los temores eran abundantes y el mal que los provocaba omnipresente y poderoso. Escoger un puñado de fuentes muy específicas en un segmento temporal tan breve -un siglo-, como hemos hecho, no puede servir más que de sondeo, sin que se puedan observar evoluciones y variaciones de tendencia, creándose una imagen superficial y tal vez equívoca. Pero en cualquier caso, el tema merece de más reflexiones de las que ha cosechado hasta ahora ${ }^{99}$, añadiéndose estas a los trabajos sobre las estructuras mentales del momento.

En segundo lugar, el agua, como el resto de la naturaleza, es siempre salvaje, pese a que en última instancia sea una muestra más de la autoridad de Dios a los ojos humanos. Se puede tratar de domesticar, aprovechar, conducir, más nunca se domina en su plenitud. Cuando hablamos del mar, la indefensión es absoluta. Como diría Juan Manuel en su Libro del caballero y el escudero, la mar es como los grandes señores: de naturaleza siempre mansos y de buen talante, pero prestos a ensañarse y embravecer si sufren desafueros (bien sea el viento para el mar o bien las provocaciones para el hombre), recibiendo su ira tanto los culpables como los inocentes ${ }^{100}$. La sociedad medieval es plenamente consciente de ello, como se demuestra floridamente a través de su narrativa. Un bello episodio en Tafur explica la ceremonia veneciana del día de la Ascensión, por el cual periódicamente desposaban al mar con la tierra "por aplacar su furia, que ellos sobre la mar están fundados e en la mar traen cuanto tienen". ${ }^{101}$ La imperiosa necesidad -además de los pingües beneficios- de tener cerca al agua no deja alternativas, los riesgos han de sortearse. Su difícilmente predecible comportamiento hace de la relación humana con ella durante el Medievo una aventura trepidante que estimula el ingenio, la técnica, las artes y, en fin, el dinamismo histórico de nuestras sociedades.

Fecha de recepción: 19 de noviembre de 2014

Fecha de aceptación: 22 de enero de 2015

99 Destacamos los interesantes artículos de Victoria CiRLot, "Escenas de terror en la literatura artúrica", Literatura y fantasía en la Edad Media, Juan Paredes Núñez (ed.), Universidad de Granada, Granada, 1989, pp. 193-203 y de María del Carmen CARLÉ, "Los miedos medievales (Castilla, siglo XV)", Estudios de Historia de España, 4 (1991), pp. 109-157.

100 Juan Manuel, "Libro del cavallero et del escudero", Obras Completas don Juan Manuel..., pp. 434-435, cap. XLVII. Al hilo de las semejanzas encontradas con el mar, tenemos una elegante comparación entre éste y la corte del rey en Las Siete Partidas del rey don Alfonso X el Sabio..., t. 2, Partida II, Título IX, Ley XXVIII, pp. 83-85.

101 Pero Tafur, Andanças e viajes..., p. 173. 